University of Nebraska - Lincoln

DigitalCommons@University of Nebraska - Lincoln

\title{
Efficacy of Translocations for Restoring Populations of Black- Tailed Prairie Dogs
}

\author{
Jo Ann L. D. Dullum \\ Charles M. Russell National Wildlife Refuge, United States Fish and Wildlife Servic \\ Kerry R. Foresman \\ : Division of Biological Sciences, University of Montana, Missoula, MT \\ Marc R. Matchett \\ Charles M. Russell National Wildlife Refuge, United States Fish and Wildlife Servic
}

Follow this and additional works at: https://digitalcommons.unl.edu/usfwspubs

Part of the Aquaculture and Fisheries Commons

Dullum, Jo Ann L. D.; Foresman, Kerry R.; and Matchett, Marc R., "Efficacy of Translocations for Restoring Populations of Black-Tailed Prairie Dogs" (2005). US Fish \& Wildlife Publications. 30.

https://digitalcommons.unl.edu/usfwspubs/30

This Article is brought to you for free and open access by the US Fish \& Wildlife Service at DigitalCommons@University of Nebraska - Lincoln. It has been accepted for inclusion in US Fish \& Wildlife Publications by an authorized administrator of DigitalCommons@University of Nebraska - Lincoln. 


\section{allen press}

Efficacy of Translocations for Restoring Populations of Black-Tailed Prairie Dogs

Author(s): Jo Ann L. D. Dullum, Kerry R. Foresman, Marc R. Matchett

Source: Wildlife Society Bulletin, Vol. 33, No. 3 (Autumn, 2005), pp. 842-850

Published by: Allen Press

Stable URL: http://www.jstor.org/stable/3785020

Accessed: 23/06/2009 00:31

Your use of the JSTOR archive indicates your acceptance of JSTOR's Terms and Conditions of Use, available at http://www.jstor.org/page/info/about/policies/terms.jsp. JSTOR's Terms and Conditions of Use provides, in part, that unless you have obtained prior permission, you may not download an entire issue of a journal or multiple copies of articles, and you may use content in the JSTOR archive only for your personal, non-commercial use.

Please contact the publisher regarding any further use of this work. Publisher contact information may be obtained at http://www.jstor.org/action/showPublisher?publisherCode=acg.

Each copy of any part of a JSTOR transmission must contain the same copyright notice that appears on the screen or printed page of such transmission.

JSTOR is a not-for-profit organization founded in 1995 to build trusted digital archives for scholarship. We work with the scholarly community to preserve their work and the materials they rely upon, and to build a common research platform that promotes the discovery and use of these resources. For more information about JSTOR, please contact support@ jstor.org. 


\title{
Efficacy of translocations for restoring populations of black-tailed prairie dogs
}

\author{
Jo Ann L. D. Dullum, Kerry R. Foresman, and Marc R. Matchett
}

Abstract We evaluated translocation as a method to promote recovery of black-tailed prairie dogs (Cynomys ludovicianus) after plague-induced population declines in colonies at the Charles M. Russell National Wildlife Refuge, Montana. We translocated prairie dogs in June of 1999 and evaluated the effects of translocation on colony area 1 year and 4 years later. We also assessed effects of release group size and estimated rates of population growth and survival. Initial size of experimental colonies was categorized as inactive (0 ha), small (0.1-2.0 ha), or large (2.0-6.6 ha); numbers of prairie dogs translocated to each colony size class were 0 (control), 60, and 120. Among inactive colonies, the control remained inactive and the colony receiving 60 prairie dogs grew to 1.5 ha by 2000 and after a second release in 2002 was 1.9 ha in 2003 . The colony receiving 120 grew to 3.3 ha by 2000 and decreased to 2.6 ha by 2003 . Patterns on small and large colonies after 1 year were less dramatic, but in each case the proportional increase in colony area was lowest on the control and highest on the colony receiving 120 prairie dogs. Patterns were more difficult to discern 4 years after translocations. It appears that as large colonies approach historic size, area growth decreases and is slower than on small colonies. Experimental colonies grew 24.6 ha $(315 \%)$ by 2000 and 72.1 ha $(924 \%)$ in 4 years compared to non-experimental colonies of similar size that grew 6.5 ha (23\%) in 1 year and 26.5 ha (93\%) by 2003. Monthly survival rates of prairie dogs during the first 3 months following translocation were higher on large colonies $(0.79,95 \% \mathrm{Cl}=0.75-0.82)$ than on small $(0.67,95 \% \mathrm{Cl}=0.62-0.72)$ or inactive colonies, $(0.63,95 \% \mathrm{Cl}=0.57-0.68)$. Monthly survival rates were relatively high (0.88-1.0) during subsequent intervals and did not vary among initial colony size classes. Recapture rates for all colonies were higher during the fall trapping session (0.83, $95 \% \mathrm{Cl}=0.76-0.90)$ than in the winter $(0.59,95 \% \mathrm{Cl}=0.49-0.69)$. Translocation was effective for restoration of prairie dog populations, particularly on inactive colonies.

Key words black-footed ferret, Cynomys ludovicianus, Montana, prairie dog, recapture, survival, translocation

Black-tailed prairie dogs (Cynomys ludovicianus, hereafter prairie dogs) are colonial, burrowing, herbivorous rodents. Colonies are divided into coteries, which are polygynous units made up of related females, their young, and an unrelated adult male. Prairie dogs live to be about $4-5$ years old, and most become reproductively mature at 2 years of age and breed only once per year (Hoogland 2001). An average of 4-5 pups emerges in May (Knowles 1987). Dispersal occurs from mid-
May to mid-July, with an average distance of $2.4 \mathrm{~km}$ and a maximum known distance of $10 \mathrm{~km}$ (Knowles 1985, Garrett and Franklin 1988).

Prairie dog range in the early 1900 s reached from southern Saskatchewan southward across the Great Plains to northern Mexico. Although prairie dog colonies once covered up to $40,000,000$ ha (Knowles and Knowles 1994), current estimates place the area within a similar range but occupied at only 1-2\% of historic levels (Miller et al. 1990).

Address for Jo Ann L. D. Dullum and Marc R. Matchett: Charles M. Russell National Wildlife Refuge, United States Fish and Wildlife Service, P.O. Box 110, 333 Airport Road, Lewistown, MT 59457, USA; e-mail for Dullum: joann_dullum@fws.gov. Address for Kerry R. Foresman: Division of Biological Sciences, University of Montana, Missoula, MT 59812, USA. 
Primary causes of the decline and isolation of colonies were eradication programs based on poisoning and shooting, conversion of grassland to cropland, and sylvatic plague (Yersinia pestis) (Campbell and Clark 1982, Knowles and Knowles 1994, Knowles 1995).

The endangered black-footed ferret (Mustela nigripes) depends solely on prairie dogs for food and on prairie dog burrows for shelter (Henderson et al. 1969, Hillman and Linder 1973, Clark 1978, Hillman and Clark 1980). The North Central Montana Complex, located in portions of Phillips and Blaine counties, Montana, was designated a black-footed ferret reintroduction site by the Montana Black-footed Ferret Working Group and the Black-footed Ferret Interstate Coordinating Committee in April 1992 due to its approximately 10,500 ha of prairie dogs (Figure 1). Area of active prairie dog colonies on Charles M. Russell National Wildlife Refuge (CMR) within the ferret reintroduction area declined approximately $40 \%$ following a plague outbreak beginning in 1992, then declined another $7 \%$ between 1993 and 1997. Large portions of many colonies and some entire colonies became inactive at that time (Knowles 1998). Sylvatic plague appeared to be the primary cause of the decline (Matchett 1997). Although no cases of plague-infected fleas (Oropsylla spp., Pulex spp.) or prairie dogs were documented in this area at that time, plague antibodies were found in $67 \%$ of carnivores collected in the area from 1993-1999 (Matchett 1999). Plague often kills prairie dogs so quickly that antibodies do not have time to form (Poland and Barnes 1979), and carcasses may not be found because they die underground or have been quickly scavenged. Although colonies that have declined from shooting or poisoning may re-establish naturally within a few years, those decimated by plague seem to re-establish more slowly, if at all. Plague often affects nearby source colonies that otherwise could provide immigrants for recolonization (Knowles 1986).

The long-term decline in continental prairie dog populations due to plague, poisoning, unregulated shooting, destruction and adverse modifications of habitat, and legislatively mandated eradication programs led the United States Fish and Wildlife Service (USFWS) in 2000 to find that listing the prairie dog for protection under the Endangered Species Act was warranted but that higher-priority species precluded listing it at that time. The prairie dog was removed from the candidate list in August 2004. As emphasis shifts from control to conserva-

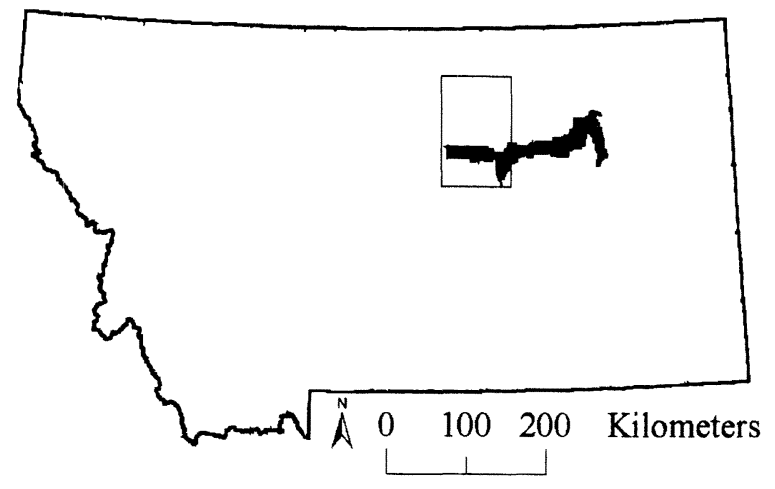

Figure 1. A portion of the Charles M. Russell National Wildlife Refuge (CMR) in northeastern Montana is encompassed in the North Central Montana Complex, established for black-footed ferret reintroduction. Prairie dog colonies throughout Phillips County and CMR were reduced by plague outbreak from 1992-1996.

tion of prairie dogs, managers need to know the effectiveness of translocations (compared to natural recolonization) in restoring colonies extirpated or severely reduced by plague or other causes.

Current changes in prairie dog populations in Phillips County, Montana were unclear, and opinions on population status and appropriate management strategies differed widely. In a preliminary effort to restore local prairie dog populations and test translocation methods, prairie dogs were translocated in 1997-1998 to colonies impacted by plague on CMR (Dullum and Durbian 1997), and results from that effort guided the design and techniques used in subsequent translocations (Dullum 2001).

Our primary objectives were to evaluate the overall effects of translocation on colony area 1 year and 4 years after release, compare colony growth in experimental colonies to growth in other nonexperimental colonies across western CMR, evaluate effects of initial colony size and translocation group size on translocation success, estimate rates of population growth in augmented versus nonaugmented colonies, and estimate survival of translocated prairie dogs.

\section{Study area}

We conducted this study in north-central Montana, on and near CMR. We trapped prairie dogs for translocation on private lands in central Phillips County, 50-70 km north of CMR, where landowners desired reduced populations. We translocated prairie dogs to 6 of 9 experimental colonies located in the Phillips County portion of CMR. We also sur- 
veyed 47 nonexperimental colonies on western CMR to estimate natural recolonization rates.

Prairie dogs on CMR are restricted to level areas $(<12 \%$ slope $)$ of grassland and shrub-grassland landscapes and clay-loam soils (Knowles 1982, Reading and Matchett 1997, Proctor 1998). Suitable areas on CMR often are constricted by steep "breaks" topography dominated by ponderosa pine (Pinus ponderosa) and Rocky Mountain juniper (Juniperus scopulorum). Shrub-grassland habitats in this area are dominated by western wheatgrass (Pascopyrum smithii), blue gramma (Bouteloua gracilis), and big sagebrush (Artemisia tridentata).

Plant species found on colonies included fringed sagewort (Artemisia frigida), prairie dogweed (Dyssodia papposa), broom snakeweed (Gutierrezia sarothrae), American milkvetch (Astragalus americanus), nuttal monolepis (Monolepis nuttalliana), woolly plaintain (Plantago patagonica), prostrate knotweed (Polygonum aviculare), tumblegrass (Schedonnardus paniculatus), and prickly pear cactus (Opuntia polyacantha).

\section{Methods}

We evaluated translocation using a $3 \times 3$ design; 3 group sizes of prairie dogs ( 0 [control], 60 , and 120) were translocated to 3 size classes of colonies (inactive [0 ha], small [0.10-2.0 ha], and large [2.0-6.6 ha], Table 1). All experimental colonies were substantially reduced in size by plague $(86-100 \%)$, so terminology is relative. The experimental colonies were all very small compared to other colonies within Phillips County, where a "large" colony was $>100$ ha.

We drilled 30 holes $(8 \mathrm{~cm}$ diameter $\times 60 \mathrm{~cm}$ deep, $45^{\circ}$ below horizontal) at each release site to provide immediate shelter and to reduce mortality or dispersal during the first few days after release (Dullum and Durbian 1997). These holes were distributed over a 0.5 -ha area using a truck-mounted auger. Prairie dogs prefer areas with vegetation $<15$ $\mathrm{cm}$ tall (Knowles 1982), so we mowed the 2 release sites that had vegetation $>15 \mathrm{~cm}$.

We trapped prairie dogs in the source area from 22 June 1999-12 July 1999 following a protocol approved by the University of Montana Institutional Animal Care and Use Committee. We baited Tomahawk live traps $(15.2 \mathrm{~cm} \times 15.2 \mathrm{~cm} \times 0.6 \mathrm{~m})$ with rolled oats or a mixture of corn, oats, barley, and molasses. We prebaited traps for 48 hours, then set them for capture and checked them twice each day, at midday and late evening. We closed traps during periods of inclement weather to minimize stress on captured animals. We attempted to keep animals from adjacent colony sections together throughout the trapping and translocation process by transferring captured prairie dogs to holding cages $(90 \mathrm{~cm} \times 90$ $\mathrm{cm} \times 250 \mathrm{~cm})$ made of wire mesh $(25 \mathrm{~cm} \times 50 \mathrm{~cm})$.

We transported and released prairie dogs captured in the midday session the same afternoon, but we held those captured in the evening overnight and released them the next afternoon. We fed and watered prairie dogs held overnight and kept them in holding cages placed inside a horse trailer to protect them from elements and predation.

Table 1. Total number of prairie dogs released on 9 experimental colonies on Charles M. Russell National Wildlife Refuge (CMR), Montana, 1999.

\begin{tabular}{|c|c|c|c|c|c|c|c|c|c|}
\hline \multirow[b]{2}{*}{ Initial size } & \multicolumn{2}{|c|}{ Colony area } & \multirow{2}{*}{$\begin{array}{c}\text { Nearest } \\
\text { colony }(\mathrm{km})^{\mathrm{C}}\end{array}$} & \multirow{2}{*}{$\begin{array}{c}\text { Colony } \\
\text { name }\end{array}$} & \multirow[b]{2}{*}{ Released } & \multicolumn{2}{|c|}{ Male } & \multicolumn{2}{|c|}{ Female } \\
\hline & $\mathrm{Ha}^{\mathrm{a}}$ & $\mathrm{Ha} \mathrm{b}^{\mathrm{b}}$ & & & & Adult & Juvenile & Adult & Juvenile \\
\hline \multirow[t]{3}{*}{ Inactive } & 24.8 & 0 & 1.0 & Agate & 0 & 0 & 0 & 0 & 0 \\
\hline & 21.0 & 0 & 2.0 & Taint & 60 & 16 & 10 & 14 & 20 \\
\hline & $146.3^{-}$ & 0 & 1.0 & Big Snowy & 120 & 24 & 20 & 36 & 40 \\
\hline \multirow[t]{3}{*}{ Small } & 397.9 & 1.1 & 0.5 & N. Manning & 0 & 0 & 0 & 0 & 0 \\
\hline & 35.3 & 1.4 & 3.0 & E. Robinson & 64 & 17 & 10 & 16 & 21 \\
\hline & 37.2 & 0.3 & 2.0 & S. Buckskin & 121 & 27 & 21 & 33 & 40 \\
\hline \multirow[t]{3}{*}{ Large } & 147.0 & 6.6 & 0.5 & S. Manning & 0 & 0 & 0 & 0 & 0 \\
\hline & 32.3 & 2.6 & 2.0 & N. Buckskin & 60 & 14 & 10 & 16 & 20 \\
\hline & 25.7 & 3.5 & 3.5 & S. Dead Calf & 119 & 34 & 20 & 25 & 40 \\
\hline Totals & & & & & 544 & 132 & 91 & 140 & 181 \\
\hline
\end{tabular}


We dusted prairie dogs upon capture as a precaution against plague using commercial flea powder for pets, following label instructions. We marked prairie dogs with dye (Rodol $\mathrm{D}^{\circledR}$, Jos. H. Lowenstein \& Sons, Inc. Brooklyn, N.Y., or Clairol ${ }^{\circledR}$, Stamford, Conn., black hair dye) for postrelease observation and tagged them with a uniquely numbered tag in each ear for estimating survival.

Age and sex composition on release sites was 40 adult females, 20 adult males, and 60 juveniles on colonies where 120 prairie dogs were released, and 20 adult females, 10 adult males, and 30 juveniles on colonies where 60 were released. We released prairie dogs directly into pre-existing burrows or augered holes in abandoned areas of the release colonies. We released portions of the release groups over 1 or more days until the goal was reached, placing up to 2 prairie dogs per augered hole and up to 8 prairie dogs per pre-existing burrow. We monitored translocation colonies for 3 days following each release, 1 hour per day.

All colonies on CMR were mapped in 1988 by USFWS personnel using topographic maps and aerial photographs. These data provided a baseline for comparison to 1999 colony area and estimation of change. We conducted all mapping from 1998-2003 by riding an all-terrain vehicle (ATV) or walking around the outermost active burrows (prairie dog, fresh scat, or fresh digging present) and recording locations every second using a Trimble Global Positioning System (GPS, $\leq 3 \mathrm{~m}$ accuracy). We flagged the perimeter prior to mapping, after which an assistant drove an ATV 5-7 $\mathrm{m}$ in front of the GPS operator, pointing to active burrows that comprised the actual perimeter.

We mapped experimental colonies once per year in 1998 and 2003 and twice in 1999 (1 month before translocation and 2 months after). We selected 46 nonexperimental colonies for comparison from those mapped in 1988, representing a range of historic (1988-1999) decline from $0-100 \%$ to describe the general pattern of change occurring in colonies on western CMR in the absence of translocation (inactive [0 ha], small [0.10-2.0 ha], large [2.0-6.6 ha], and extra-large [ $>6.6 \mathrm{ha}])$.

Population estimates can be calculated using capture-mark-recapture, estimates from active burrows, or visual counts. We found minor differences between population estimates taken from active burrows versus those using the maximum population estimate from visual counts (Dullum 2001); therefore, we used visual counts to estimate population size.
We modified the visual count protocol established by Severson and Plumb (1998) for prairie dogs. We divided colonies into sections that could be seen in their entirety from one point and then performed counts on each section separately. We made counts while standing on top of an ATV, 10-50 $\mathrm{m}$ from prairie dogs, to minimize observer influence on prairie dog behavior. We performed counts over 3 consecutive days for 4 15-minute intervals, during the peak morning activity period (0700-1000 hours) during fair, relatively calm wind conditions. Maximum counts were highly correlated $\left(R^{2}=0.942\right.$, Knowles 1982) with the actual population and averaged $85 \%$ of the total, (i.e., population $=$ maximum count $/ 0.85$ ). We refer to this as the maximum population estimate.

We calculated annual growth rate $(\lambda)$ for each colony using the equation, $\lambda=N_{\mathrm{t}} / N_{\mathrm{o}}$, where $N_{\mathrm{t}}$ was population size at time t (June 2000) and $N_{\mathrm{o}}$ was initial population size (June 1999).

We used capture-recapture methods and the Cormack-Jolly-Seber model to estimate and test biological hypotheses regarding survival (Lancia et al. 1994). We began with the most general model that allowed survival rates $\left(\Phi_{\mathrm{i}}\right)$ and recapture rates $\left(p_{\mathrm{i}}\right)$ (of the marked prairie dogs alive at time period $i$, the likelihood a marked animal was captured during a trapping period) to vary by release size, age, sex, initial colony size, colony, and time. We used program MARK (White and Burnham 1999) to estimate parameters, $\Phi_{\mathrm{i}}$ and $p_{\mathrm{i}}$, where $\mathrm{i}$ was the release or recapture period $(1=$ release June 1999, 2 = October 1999, 3= March 2000, 4=July 2000); $\Phi_{i}$, was the probability of surviving from period i to period $\mathrm{i}+1$; and $p_{\mathrm{i}}$ was the probability of recapture, the number of marked animals captured during a trapping session, in period i. Permanent dispersal from the sampling area was equivalent to mortality in this analysis. Median interval length between each recapture was 3.5 months for periods $1-2,5.5$ for $2-3$, and 4.0 for $3-4$. We assessed the goodness-offit using a parametric bootstrap method with 100 simulations (model deviance $=29.0$, mean simulated deviance $=23.3, P=0.19, c=1.24$ ). We then successively removed variation from the most general model. From these models, we determined the best model based on Akaike's Information Criterion (AIC). The best model was then used to obtain maximum-likelihood estimates of monthly survival and recapture probabilities. We applied a variance inflation factor to adjust for overdispersion (c) and calculated the quasi-AIC (QAIC, Burnham and 
Anderson 1992),

$$
\mathrm{QAIC}=-2 \ln (L) / c+2 \mathrm{np},
$$

$\mathrm{np}=$ the number of estimable parameters in the model.

Parameters $\Phi_{3} p_{4}$ were not estimable separately under this model, so we fixed the last capture parameter and set it equal to 1.0. We obtained the 95\% CI by back-transforming the beta CI using the sine link $\{[$ sine $($ beta $)+1] / 2\}$ because our parameter estimates in the second time interval were close to the boundary (1.0) causing the CI to vary from expected.

\section{Results}

Colony area was correlated with prairie dog populations $\left(R^{2}=0.62\right)$ and number of active burrows $\left(R^{2}=0.93\right)$ (Dullum 2001). We used colony area as the primary indicator of translocation effect because of these correlations and ease of measuring colony size.

Among inactive experimental colonies, the control remained inactive 1 year after translocation. The colony receiving 60 prairie dogs grew to 1.5 ha, and the colony receiving 120 grew to 3.3 ha (Table 2). Patterns of growth in small and large experimental colonies were less dramatic, but in each case the first year, the proportional increase in colony area was lowest for control colonies, inter- mediate on colonies receiving 60 prairie dogs, and highest on colonies with 120 released (Table 2). Active colonies receiving 60 prairie dogs showed a combined increase of 7.3 ha (183\%) and those receiving 120 prairie dogs a combined increase of 12.6 ha (332\%) in 2000, for a total increase of 19.9 ha $(255 \%)$.

Four years later, among inactive experimental colonies, the control remained inactive. The colony receiving 60 prairie dogs received another 120 in 2002 and was 1.9 ha in 2003 . The inactive experimental colony receiving 120 decreased to 2.6 ha (Table 2). Active colonies receiving 60 prairie dogs showed a combined increase of 30.7 ha $(768 \%)$ after 4 years. Those receiving 120 prairie dogs showed a combined increase of 36.9 ha ( $971 \%$ ) by 2003 , for a total increase of 67.6 ha $(867 \%)$ over 4 years. Control colonies were located within $0.5 \mathrm{~km}$ of 1997-1998 translocation sites and by 2003 had merged with these sites. Using the 1999 combined colony acreage, including the 1997-1998 translocation area, the control colonies had increased to 93.8 ha $(580 \%)$ and 73.2 ha $(800 \%)$ by 2003 (Table 2 ).

Experimental colonies were between $0-14 \%$ of their historic (1988) size in 1999 prior to translocation, and all were still less than $20 \%$ of their historic size in 2000 , except for the large colony with 120 released, which had grown to $44 \%$ of the 1988 size. Patterns of growth were more difficult to discern 4 years following translocations. It appeared large colonies were growing more slowly than

Table 2. Colony size changes on experimental colonies following prairie dog translocations on CMR, Montana, $1999-2003$.

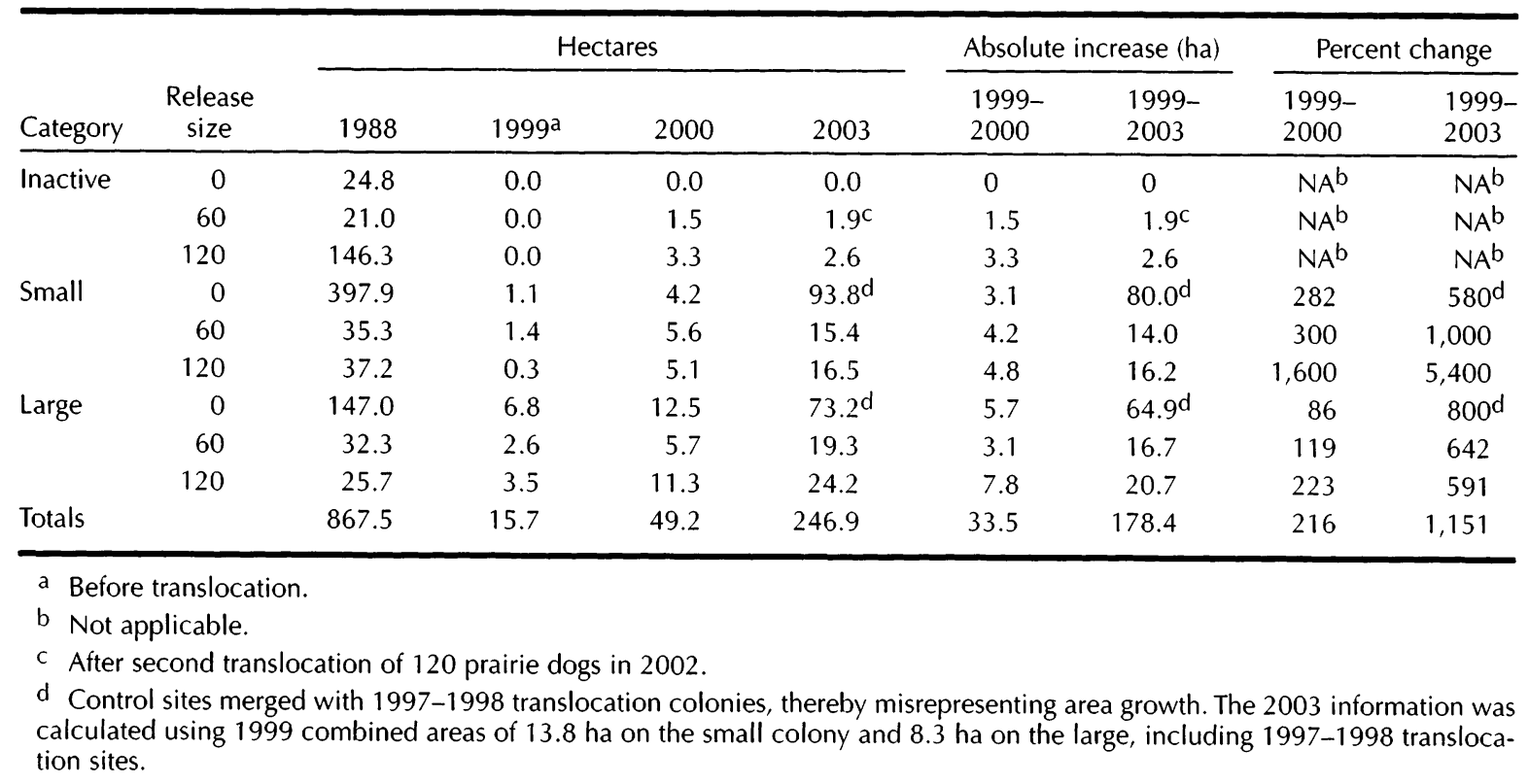


small colonies. Large release colonies were 60-94\% of historic size and grew 591-642\%. Small release colonies were both $44 \%$ of historic size and grew 1,000-5,400\% (Table 2).

Three of 14 inactive nonexperimental colonies were naturally recolonized, showing a combined increase of 1.1 ha by 2000 . One inactive colony received translocations in 2002 and one was not mapped in 2003, so both were removed from analysis; therefore, 5 of 12 inactive colonies grew 1.3 ha by 2003 . The 3 small nonexperimental colonies increased a total of 1.7 ha (36\%) by 2000 and 10.4 ha $(221 \%)$ in 4 years. Five large colonies increased a total of 3.7 ha $(16 \%)$ in 1 year and 14.7 ha $(62 \%)$ by 2003 .

Nonexperimental colonies increased in size but not to the degree of experimental colonies. Experimental release colonies $(n=6)$ in the first year grew a total 24.6 ha (315\%) compared to 6.4 ha $(23 \%)$ on nonexperimental colonies of similar size $(n=22)$. Experimental colonies $(n=6)$ grew a total 72.1 ha $(924 \%)$ by 2003 compared to 26.5 ha (93\%) on nonexperimental colonies of similar size $(n=20)$.

Extra-large nonexperimental colonies $(n=24)$ grew 134.1 ha (9\%) in 2000 and in 4 years grew 228.4 ha $(17 \%)$. In 199916 of the 46 nonexperimental colonies were $0-14 \%$ of their historic size. These colonies increased a total of 4.5 ha $(30 \%)$ by 2000 through natural recolonization. Two colonies previously removed from analysis were removed again; therefore 10 of 14 were $<5 \%$ of historic size and 4 were between $19-48 \%$ of historic size (1988) in 2003.

Population growth rates and absolute population changes were lower on control colonies than treatment colonies. Absolute population changes were higher on colonies with 120 prairie dogs released versus colonies with 60 released (Table 3).

The best model was $\Phi_{\mathrm{G} \times \mathrm{T}} p_{\mathrm{T}}$, in which survival rate varied by initial colony size and time and recapture varied rates by time $(\mathrm{QAIC}=914.0, \mathrm{np}=$
11 , and DEV $=159.1$, Tables 4 and 5). Survival probabilities for the small $(0.67,95 \% \mathrm{CI}=0.62-0.72)$ and inactive $(0.63,95 \% \mathrm{CI}=0.57-0.68)$ colonies from June-October 1999 were significantly lower than for large colonies $(0.79,95 \% \mathrm{CI}=0.75-0.82)$. Survival rates were comparatively high $(0.88-1.0)$ during subsequent intervals and did not vary among initial colony size classes (Table 4).

Recapture rates were significantly higher in October $1999(0.83,95 \% \mathrm{CI}=0.76-0.90)$ than in March $2000(0.59,95 \% \mathrm{CI}=0.49-0.69$, Table 5). Thirty-three recaptured prairie dogs lost 1 tag, and 2 lost both ear tags as indicated by torn ears. During 66 trapping occasions from October 1999 to July 2000,16 of the prairie dogs captured were unmarked adults. Additionally, 97 juveniles were trapped in July 2000 within the release areas.

\section{Discussion}

Translocation shows considerable promise for restoring prairie dogs to areas decimated by plague or other factors, providing managers with a technique to re-establish inactive colonies or promote more rapid growth in remnant colonies. Growth of colony area and prairie dog populations was considerably greater on treatment colonies than on control colonies 1 year after translocation. Similarly, growth of colony area was greater on experimental colonies than on nonexperimental colonies. Greater area growth on experimental control colonies versus nonexperimental colonies was possibly due to translocations near experimen-

Table 3. Annual growth rate $(\lambda)$ from 1999-2000 on 9 experimental CMR colonies in Montana based on the minimum prairie dog population size.

\begin{tabular}{|c|c|c|c|c|c|}
\hline \multirow[b]{2}{*}{ Category } & \multirow[b]{2}{*}{ Number released } & \multicolumn{2}{|c|}{ Minimum population size } & \multirow{2}{*}{$\begin{array}{c}\text { Absolute } \\
\text { population increase }\end{array}$} & \multirow[b]{2}{*}{$\lambda$} \\
\hline & & June $1999 b$ & July 2000 & & \\
\hline \multirow[t]{3}{*}{ Inactive } & 0 & 0 & 0 & 0 & $N A^{C}$ \\
\hline & 60 & 0 & 2 & 2 & $N A^{C}$ \\
\hline & 120 & 0 & 24 & 24 & $N A^{C}$ \\
\hline \multirow[t]{3}{*}{ Small } & 0 & 10 & 14 & 4 & 1.40 \\
\hline & 64 & 15 & 51 & 36 & 3.40 \\
\hline & 121 & 3 & 42 & 39 & 14.0 \\
\hline \multirow[t]{3}{*}{ Large } & 0 & 51 & 81 & 30 & 1.59 \\
\hline & 60 & 19 & 41 & 22 & 2.18 \\
\hline & 119 & 103 & 220 & 117 & 2.14 \\
\hline Totals & 544 & 201 & 475 & 274 & $N A^{C}$ \\
\hline
\end{tabular}

\footnotetext{
a Highest of 12 counts conducted on each colony.

b Before translocation.

c Not applicable.
} 
Table 4. Monthly prairie dog survival $\left(\Phi_{\mathrm{i}}\right)$ rates for 4 occasions of capture and release on CMR, Montana,1999-2000.

\begin{tabular}{|c|c|c|c|c|c|c|}
\hline \multirow[b]{2}{*}{ Category } & \multirow[b]{2}{*}{ Interval } & \multicolumn{2}{|c|}{ Monthly Survival rate } & \multirow[b]{2}{*}{ SE } & \multirow[b]{2}{*}{$-95 \% \mathrm{Cl}$} & \multirow[b]{2}{*}{$+95 \% \mathrm{Cl}$} \\
\hline & & Over interval & Within interval & & & \\
\hline \multirow[t]{3}{*}{ Inactive } & $\Phi_{1}^{\mathrm{a}}$ & 0.20 & 0.63 & 0.029 & 0.57 & 0.68 \\
\hline & $\Phi_{2}^{b}$ & 0.50 & 0.88 & 0.032 & 0.81 & 0.94 \\
\hline & $\Phi_{3} p_{4}{ }^{c}$ & 0.81 & 0.95 & 0.035 & 0.86 & 0.99 \\
\hline \multirow[t]{3}{*}{ Small } & $\Phi_{1}^{a}$ & 0.25 & 0.67 & 0.026 & 0.62 & 0.72 \\
\hline & $\Phi_{2}^{b}$ & 0.83 & 0.97 & 0.020 & 0.92 & 1.00 \\
\hline & $\Phi_{3} p_{4}^{c}$ & 0.65 & 0.90 & 0.033 & 0.83 & 0.95 \\
\hline \multirow[t]{3}{*}{ Large } & $\Phi_{1}^{\mathrm{a}}$ & 0.43 & 0.79 & 0.020 & 0.75 & 0.82 \\
\hline & $\Phi_{2}^{b}$ & 0.98 & 1.0 & 0.011 & 0.93 & 1.00 \\
\hline & $\Phi_{3} p_{4}{ }^{\mathrm{C}}$ & 0.69 & 0.91 & 0.022 & 0.86 & 0.95 \\
\hline
\end{tabular}

a June-October 1999.

b October 1999-March 2000.

c March-July 2000.

tal colonies in 1997 and 1998 or possibly larger distances between nonexperimental colonies and source colonies. Releasing 120 prairie dogs produced proportionally larger increase in colony sizes than releasing 60 . Population growth rate was highest on inactive and small colonies where we released 120 prairie dogs.

Colony growth slows as large colonies approach historic (1988) size as indicated 4 years after translocations. The expansion rate decreases as colonies reach their maximum area potential and prairie dogs attempt to move into previously uncolonized areas.

Translocations are considered successful if the result is a self-sustaining population (Griffith et al. 1989). We considered 5 out of 6 of the release sites as successful. However, the inactive colony with 60 prairie dogs released did not result in a self-sustaining population because only 2 adult females sur-

Table 5. Monthly prairie dog recapture $\left(p_{\mathrm{i}}\right)$ rates for 4 occasions of capture and release on CMR, Montana, 1999-2000.

\begin{tabular}{lccccc}
\hline & & \multicolumn{4}{c}{ Recapture } \\
\cline { 3 - 6 } Category & Interval & Rate & $\begin{array}{c}\text { Standard } \\
\text { error }\end{array}$ & $\begin{array}{c}-95 \% \\
\mathrm{Cl}\end{array}$ & $\begin{array}{c}+95 \% \\
\mathrm{Cl}\end{array}$ \\
\hline All & $p_{2}{ }^{\mathrm{a}}$ & 0.83 & 0.035 & 0.76 & 0.90 \\
& $p_{3}{ }^{\mathrm{b}}$ & 0.59 & 0.051 & 0.49 & 0.69 \\
& $p_{4}{ }^{\mathrm{c}}$ & 1.00 & 0.0 & 1.00 & 1.00 \\
\hline
\end{tabular}

\footnotetext{
a October 1999

b March 2000.

c July 2000 .
}

vived 1 year after release. We translocated 120 prairie dogs to this site in 2002. More prairie dogs may eventually immigrate to this site, but few had done so by 2003 . Inactive release colonies 4 years after translocations did not appear to be growing as rapidly as expected. One possible explanation may be that prairie dog retention for these areas was low and few prairie dogs remained in the area following translocations.

Robinette et al. (1995) found survival of translocated prairie dogs higher in release groups of 60 than in groups of 10 and 30 . We found no significant difference in survival between release groups of 60 and 120 but did find an effect of initial colony size. Prairie dogs translocated to large colonies experienced higher survival than those translocated to small or inactive colonies, possibly the result of a sufficient prairie dog population to detect and alert to predators.

The significant decline in capture rate in March 2000 likely was a function of reduced prairie dog activity during cold weather. We were interested in the reestablishment or growth of prairie dog colonies and the number of prairie dogs remaining at release sites was of primary concern. Therefore, separating mortality from emigration was not possible in our analysis.

We used colony area to evaluate the effect of translocation because it was the metric most commonly used in management and was used to determine status and trend by the USFWS for listing decisions. Furthermore, we found that colony area was closely correlated with prairie dog population, and number of active burrows (Dullum 2001).

Prairie dogs released into augered holes covered themselves with soil. Those released into pre-existing burrows stayed inside, although some ventured to the entrance to scan their surroundings. Approximately 10 individuals ran to nearby roads, were captured by hand, indicative of their vulnerability, and were returned to the release site. Some prairie dogs located coterie members following 
release and displayed kin recognition behavior in the form of "kissing" and grooming (Hoogland 1995). The established translocated prairie dogs either stayed in the vicinity of the release area or moved to the perimeter of the remnant colony. We observed, immediately following release, that translocated prairie dogs were cautious and used alarm barks and jump-yips (Hoogland 1995) less than prairie dogs at control sites. We counted a higher number of juveniles the following spring at all release sites except the inactive colony where 60 prairie dogs were released.

\section{Management implications and research recommendations}

Prairie dog colonies can be re-established through translocations. We recommend releasing a minimum of 120 prairie dogs for greater proportional increases in colony size. Even with success in re-establishing small areas with prairie dogs, it will take approximately 9 years to return to preplague levels using an average of $23 \%$ growth found on the nonexperimental colonies (0-6.6 ha). Survival rates of translocated prairie dogs were higher for prairie dogs released on large colonies. On inactive or small colonies, initial survival rates may be improved and dispersal rates limited by releasing prairie dogs over a few weeks (Jacquart et al. 1986). Release the first group and allow them to excavate burrows over a period of days, then release the rest of the group directly into these burrows. Improve retention rate at the release site within the first week after release, possibly through supplemental feeding (Truett et. al 2001). Although not necessary during this study, others have controlled badgers (Taxidea taxus) on release sites to increase survival and retention after release (Jacquart et al. 1986, Coffeen and Pederson 1989, Truett et al. 2001). Research should focus on determining plague vector dynamics, ecology, and epizootic management. Government agencies, conservation organizations, and private land stewards should work to improve the negative attitudes toward prairie dogs through education and landowner incentives to allow prairie dogs to continue their pivotal role in the functioning of prairie ecosystems.

Acknowledgments. Thanks to I. J. Ball and D. Pletscher for extensive help during analysis. We thank the private landowners of Phillips County for permission to trap prairie dogs on their land. We thank the staff of the Charles M. Russell National Wildlife Refuge for assisting in the field and providing technical support. We are indebted to the following: D. Jachowski, D. McCallum, M. Nelson, R. Nickerson, and S. Spooner. We thank M. Lindberg, L. S. Mills, and J. Graham for assisting with the analyses. We appreciate the long hours spent trapping and translocating prairie dogs and mapping colonies by D. Ausmus, F. E. Durbian III, J. P. Dullum, S. S. Henry, C. Knowles, J. Meadows, C. Miller, P. Sullivan, and D. Willingham. A special thanks to D. Phelps for help throughout the project. Thanks to USFWS for providing funding for the project.

\section{Literature cited}

Burnham, K. P., AND D. R. ANDERSON. 1992. Data-based selection of an appropriate biological model: the key to modern data analysis. Pages 16-30 in D. R. McCullough and R. H. Barrett, editors. Wildlife 2001: populations. Elsevier Applied Science, New York, New York, USA.

CAMPBELl, T.M.,AND T.W.CLARK. 1982. Colony characteristics and vertebrate associations of white-tailed and black-tailed prairie dogs in Wyoming. American Midland Naturalist 105:269-276.

Clark, T. W. 1978. Current status of the black-footed ferret in Wyoming. Journal of Wildlife Management 42:128-134.

Coffeen, M. P., and J. C. Pederson. 1989. Transplant techniques for the Utah prairie dog (Cynomys parvidrens). Utah Division of Wildlife Resources, Salt Lake City, USA.

Dullum, J. L. D. 2001. Efficacy of translocations for restoring populations of black-tailed prairie dogs in north-central Montana. Thesis, University of Montana, Missoula, USA.

Dullum, J. L. D., AND F. E. Durbian, III. 1997. Summary of the 1997 prairie dog translocation experiments No. 1-3 on the Charles M. Russell National Wildlife Refuge. Appendix 2 in M. R. Matchett, editor. Annual report of black-footed ferret recovery activities, UL Bend and Charles M. Russell National Wildlife Refuges, Southern Phillips County, Montana. United States Fish and Wildlife Service, Lewistown, Montana, USA.

Garrett, M. G., AND W. L. Frankuin. 1988. Behavioral ecology of dispersal in the black-tailed prairie dog. Journal of Mammalogy 69: 236-250.

Griffith, B., J. M. Scott, J. W. Carpenter, and C. Reed. 1989. Translocations as a species conservation tool: status and strategy. Science 245: 477-480.

Henderson, F. R., R. F. Springer,AND R. AdRian. 1969. The black-footed ferret in South Dakota. South Dakota Department of Game, Fish and Parks Technical Bulletin No. 4. South Dakota Department of Game, Fish and Parks, Pierre, USA.

Hillman, C. N., AND T.W.Clark. 1980. Mustela nigripes. Mammalian Species 126: 1-3.

Hillman, C. N., and R. L. Linder. 1973. The black-footed ferret. Pages 10-23 in R. L. Linder and C. N. Hillman, editors. Proceedings of the black-footed ferret and prairie dog workshop. South Dakota State University, Brookings, USA.

Hoogland, J. L. 1995. The black-tailed prairie dog: social life of a burrowing animal. University of Chicago Press, Chicago, Illinois, USA

Hoogland, J. L. 2001. Black-tailed, Gunnison's, and Utah prairie dogs all reproduce slowly. Journal of Mammalogy 82:917-927. 
JACQUART, H. C., J. T. FlindeRs, M. P. COFFEen, AND R. HASENYAGER. 1986. Prescriptive transplanting and monitoring of Utah prairie dog (Cynomys parvidens) populations. Thesis, Brigham Young University, Provo, USA

KNOWLEs, C. J. 1982. Habitat affinity, populations, and control of black-tailed prairie dogs on the Charles M. Russell National Wildlife Refuge. Dissertation, University of Montana, Missoula, USA.

KNOWLES, C. J. 1985. Observations on prairie dog dispersal in Montana. Prairie Naturalist 17:33-40.

KNOWLEs, C. J. 1986. Population recovery of black-tailed prairie dogs following control with zinc phosphate. Journal of Range Management 39:249-251.

KNOWLES, C. J. 1987. Reproductive ecology of black-tailed prairie dogs in Montana. Great Basin Naturalist 47:202-206.

KNowles, C. J. 1995. Summary of black-tailed prairie dog abundance and distribution on the central and northern Great Plains. FaunaWest Wildlife Consultants, Boulder, Montana, USA.

KNOWLes, C. J. 1998. Status of the black-tailed and white-tailed prairie dog in Montana. FaunaWest Wildlife Consultants, Boulder, Montana, USA

KNOWLES, C. J., AND P. R. KNOwLES. 1994. A review of black-tailed prairie dogs literature in relation to rangelands administered by the Custer National Forest. United States Department of Agriculture Custer National Forest, Billings, Montana, USA.

Lancia, R. A. J. D. Nichols, AND K. H. Pollock. 1994. Estimating the number of animals in wildlife populations. Pages 215-253 in $\mathrm{T}$. A. Bookhout, editor. Research and management techniques for wildlife and habitats. Fifth edition. The Wildlife Society, Bethesda, Maryland, USA.

MATChETT, M. R. 1997. Annual report of black-footed ferret recovery activities, UL Bend and Charles M. Russell National Wildlife Refuges, Southern Phillips County, Montana. United States Fish and Wildlife Service, Lewistown, Montana, USA.

MATCHETT, M. R. 1999. Black-footed ferret recovery activities on the UL Bend and Charles M. Russell National Wildlife Refuges, Phillips County, Montana. 1998 annual report and 5 year summary. United States Fish and Wildlife Service, Lewistown, Montana, USA.

Miller, B. J., C. Wemmer, D. E. Biggins, and R P. ReAding. 1990. A proposal to conserve black-footed ferrets and the prairie dog ecosystem. Environmental Management 14:763-769.

Poland, J. D., And A. M. Barnes. 1979. Plague. Pages 515-556 in J. H. Steele, editor. CRC handbook series in zoonoses, Section A: Bacterial, rickettsial, and mycotic diseases. CRC Press, Boca Raton, Florida, USA.

Proctor, J. 1998. A GIS model for identifying potential black-tailed prairie dog habitat in the Northern Great Plains shortgrass prairie. Thesis, University of Montana, Missoula, USA.

READING, R. P., AND M. R. MATCHETT. 1997. Attributes of black-tailed prairie dog colonies in northcentral Montana. Journal of Wildlife Management 61:664-673.

ROBINETTE,K.W.,W.F.ANDELT,AND K. P. BURNHAM. 1995. Effect of group size on survival of relocated prairie dogs. Journal of Wildlife Management 59:867-874.

SeVerson, K. E., AND G. E. Plumb. 1998. Comparison of methods to estimate population densities of black-tailed prairie dogs. Wildlife Society Bulletin 26:859-866.

Truett, J. C., J. L. D. Dullum, R. Matchett, E. Owens, AND D. Seery. 2001. Translocating prairie dogs: a review. Wildlife Society Bulletin 29: 863-872.

WhITE, G. C., AND K. P. BuRnhaM. 1999. Program Mark: survival estimation from populations of marked animals. Bird Study 46 Supplement: $120-138$.

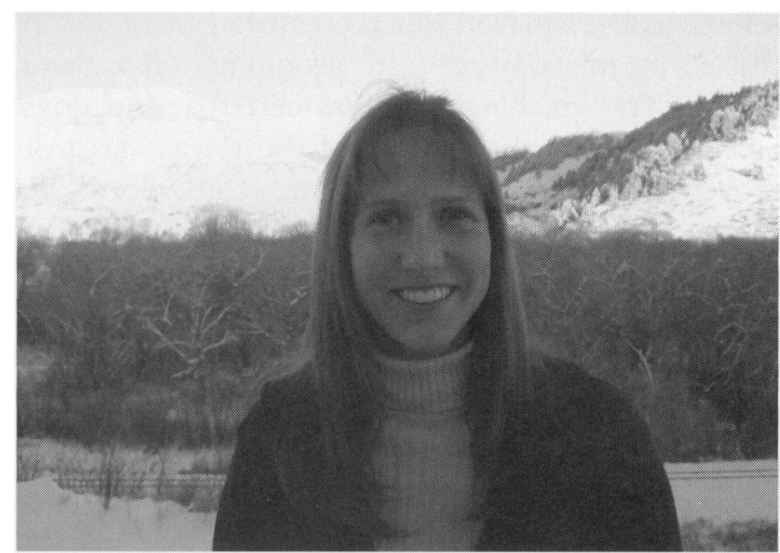

Jo Ann L. D. Dullum (photo) is a wildlife biologist for the United States Fish and Wildlife Service (USFWS) on the Charles M. Russell National Wildlife Refuge (CMR). She received her B.S. in zoology from Oregon State University in 1992 and her M.S. in wildlife biology from the University of Montana in 2001. She has been a member of The Wildlife Society for 10 years. She has worked as a research biologist in Tanzania, Idaho, Oregon, California, and Montana. In 1997 she began work at CMR, where she conducted her graduate work on the restoration of prairie dogs through the USFWS's Student Career Experience Program. Her current research interests include prairie wildlife and habitat conservation and wildlife population monitoring. Kerry R. Foresman is a professor of biology and wildlife biology at the University of Montana, where he has been on the faculty for the past 20 years. Prior to this position he was an assistant professor at the University of Rhode Island. He received his B.A. degree in zoology from the University of Montana and his M.S. and Ph.D. degrees in zoology from the University of Idaho. His research primarily focuses on the ecology of small-mammal species (shrews, bats, rodents) as well as mid-level carnivores (American marten and fisher). More recently he has turned his attention to the effects of habitat fragmentation on wildlife populations as a result of road development. This research seeks to not only document such effects but to develop strategies to mitigate these impacts (e.g. the effectiveness of wildlife overpasses, underpasses, and culverts). He has also begun collaborative studies on wildlife populations in Taiwan and Vietnam and is working closely with indigenous tribes in Taiwan to document wildlife resources so that conservation plans for historic tribal lands can be promoted with the government. Marc R. (Randy) Matchett is the senior wildlife biologist for the USFWS on the Charles M. Russell National Wildlife Refuge, where he has been employed since 1987. He has worked for a variety of state and federal agencies in Montana and Idaho on many different wildlife species and issues. Beginning with research on moose in northwestern Montana in 1981, Randy's career has been continually downsizing from work on the big game species of CMR to prairie dogs and black-footed ferrets, to fleas and plague bacteria, to sage grouse and West Nile virus interactions, and most recently to chronic wasting disease surveillance and prions. Most of Randy's time is devoted to prairie wildlife research, management, and habitat conservation efforts in association with the abundant wildlife resources of north-central Montana. Coordination among the many varied interests and values present locally and nationally create many challenges. Wife Sally and children Sam and Maggie are Randy's constant reminders of the importance of the work of wildlife professionals, and of the importance of family to wildlife professionals.

Associate editor: Murray

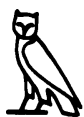

